1936), complete the record for the year 1935 and begin that for the present year. The general impression that one receives in reading over the titles is that references are gathered from more varied sources and that the bibliography is increasing much in usefulness. The last number for 1935 contains an index classified according to the subjects of the various memoirs catalogued during the year. A useful feature of both numbers is the list of references to notes or short articles that have appeared in various journals, such as NATURE, Science, etc. The first number for 1936 shows that Great Britain is represented among the collaborators by Dr. E. Tillotson, 23 Roseville Rosd, Leeds, 8, who will be glad to receive notices of papers on any seismological subjects published in Great Britain.

\section{Veterinary Education}

THE following Committee has been appointed by the Secretary of State for Scotland and the Minister of Agriculture and Fisheries "to review the facilities available for veterinary education in Great Britain in relation to the probable future demand for qualified veterinary surgeons and to report thereon, and in particular to make recommendations as to the provision which should be made from public funds in the five years 1937-42 in aid of the maintenance expenses of institutions providing veterinary education": The Right Hon. Sir Thomas Molony (ehairman), Sir James Currie, Dr. Thomas Loveday, Sir John Robertson, Mr. John Smith. Mr. V. E. Wilkins, of the Ministry of Agriculture and Fisheries, and Mr. W. N. McWilliam, of the Department of Agriculture for Scotland, have been appointed joint secretaries of the Committee.

\section{Poultry Mortality Committee: New Chairman}

ARISING out of a recommendation of the Eggs and Poultry Reorganisation Commission for England and Wales, a Committee was set up some months ago by the Secretary of State for Scotland and the Minister of Agriculture and Fisheries "to consider the present methods of supply and distribution of hatching eggs, day old chicks, and breeding stock, both generally and with particular reference to the reduction of poultry mortality; and to make recommendations for the improvement of those methods". The Committee's proceedings were however suspended by the illness, recently followed by death, of its chairman, the late Mr. F. N. Blundell. Sir Duncan Watson has now been appointed chairman of the Committee. The secretary of the Committee is Mr. V. E. Wilkins, of the Ministry of Agriculture and Fisheries.

\section{Rat Control Film}

THE Ministry of Agriculture and Fisheries has recently produced a new cinematograph film dealing with the loss and damage caused by rats and mice and the measures which may be taken for their destruction. The film, which is entitled "Your Enemy-The Rat", is available in two versions-a short sound film for display in public cinemas, and a longer silent version designed for display at exhibitions, conferences, etc. Copies of the film will be loaned free of charge. Applications for bookings should be addressed to the Secretary, Ministry of Agriculture and Fisheries, 10 Whitehall Place, London, s.W.1.

\section{Royal Prowess in Ancient Egypt}

No little interest and some amusement has been aroused by the inscribed stela of Amenhotep II discovered at Giza, on which the monarch transcends the customary royal assumption of credit for achievement by an intimate personal touch in his description of his prowess as an oarsman and athlete. The stela, which was found in the course of Prof. Selim Hassan's excavations in the neighbourhood of the Sphinx at Giza (The Times, Nov. 7), records that Amenhotep, when visiting Giza as a young man to pay homage to his ancestors Khufu and Khephren, had rowed a boat for three miles against the stream with an oar twenty ells long without fatigue, while his boatmen were tired after rowing for half a mile. As a horseman and archer he was no less remarkable. He had trained his horses to draw his chariot at a gallop without sweating, and shooting from his chariot he had pierced with an arrow copper targets which were as thick as his hand. The stela upon which is the inscription also bears above a representation of the king making offerings to a figure which is said to be identifiable as the god Ra. It was set up in the second year of Amenhotep's reign (1447 в.c.). The expedition of which Prof. Selim Hassan is in charge is engaged in clearing the whole area adjacent to the Sphinx, and with this purpose in view additional land, at present encumbered with refreshment booths, has been purchased to obviate interference with the work of excavation.

\section{Institute of Physics : London and Home Counties Branch}

The inaugural meeting of the London and Home Counties Branch of the Institute of Physics was held on November 4 under the chairmanship of Mr. E. R. Davies, director of the Kodak Research Laboratory. This, the third branch of the Institute to be formed in Great Britain, has been created in response to the desire expressed by some three hundred members resident in London and the surrounding districts. The formation of these branches serves to demonstrate the growing number of physicists in industry who wish to have opportunities for social intercourse and discussion of problems of mutual interest. At the meeting numerous suggestions were made for activities that the branch might usefully undertake; these included visits to works and industrial research laboratories, discussions on professional matters, and short groups of lectures on recent advances in physics. It was emphasized that it is not intended to hold meetings for the reading of original papers, as this is the function of the Institute's participating societies, namely the British Institute of Radiology, the Faraday Society, the Physical Society, and the Royal Meteorological Society. Full particulars of the new branch may be obtained from Dr. H. Lowery, honorary secretary of the branch, North-Western Polytechnic, Prince of Wales Road, N.W.5. 